\title{
Effects of iron surface pretreatment on kinetics of aqueous nitrate reduction
}

\author{
Ya Hsuan Liou ${ }^{\mathrm{a}, *}$, Shang-Lien Lo ${ }^{\mathrm{a}}$, Chin-Jung Lin ${ }^{\mathrm{a}}$, Wen Hui Kuan ${ }^{\mathrm{b}}$, Shih Chi Weng ${ }^{\mathrm{a}}$ \\ ${ }^{a}$ Research Center for Environmental Pollution Prevention and Control Technology, Graduate Institute of Environmental Engineering, \\ National Taiwan University, Taipei 106, Taiwan, ROC \\ ${ }^{\mathrm{b}}$ Department of Environmental and Safety Engineering, Ming-Chi Institute of Technology, \\ Taishan, Taipei hsien 243, Taiwan, ROC \\ Received 8 April 2005; accepted 27 June 2005 \\ Available online 10 August 2005
}

\begin{abstract}
Using hydrogen gas at $400^{\circ} \mathrm{C}$ to activate iron surface was proposed to remove nitrate $\left(40 \mathrm{mg} \mathrm{N} \mathrm{L}^{-1}\right)$ in a HEPES buffer solution at $\mathrm{pH}$ value between 6.5 and 7.5. Compared with the nonpretreated iron, the first-order reaction rate constant $\left(k_{\text {obs }}\right)$ was increased 4.7 times by pretreated iron, and the lag of the early period disappeared. Normalized to iron surface area concentration, the specific rate constant $\left(k_{\mathrm{SA}}\right)$ was increased approximately by a factor of 6 using hydrogen reduction $\left(0.0020 \mathrm{~min}^{-1} \mathrm{~m}^{-2} \mathrm{~L}\right.$ for nonpretreated iron and $0.0128 \mathrm{~min}^{-1} \mathrm{~m}^{-2} \mathrm{~L}$ for pretreated iron). The reactivity of aged iron covered by a complex mixture of iron oxides (soaking in nitrate solution for 60 days) were restored by hydrogen gas at $400^{\circ} \mathrm{C}$. Scanning electron microscopy (SEM) and temperature-programmed reduction (TPR) exhibited visibly cleaner without pitting and cracking and less oxygen fraction on pretreated iron surface relative to nonpretreated iron. Activation energies $\left(E_{\mathrm{a}}\right)$ of nitrate reduction over the temperature range of $10-45^{\circ} \mathrm{C}$ were $46.0 \mathrm{~kJ} \mathrm{~mol}^{-1}$ for nonpretreated iron, and $32.0 \mathrm{~kJ}$ mol ${ }^{-1}$ for pretreated iron, indicating chemical reaction control, rather than diffusion. The results indicated that this enhancement was attributed to the increase in active site concentration on iron surface by hydrogen reduction.
\end{abstract}

(C) 2005 Elsevier B.V. All rights reserved.

Keywords: Nitrate; Iron; Pretreatment; Reduction

\section{Introduction}

Iron, the most commonly used material, is a highly reductive metal for groundwater contaminated with organohalides [1-5], nitrate [6-10], heavy metals $[9,11,12]$ and radioactive elements [13]. The disappearance of contaminants is attributed to a corrosion-like process, in which the iron donates electron to reduce target pollutants, accompanied by the dissociation of water. Generally, nonpretreated commercial iron is covered with a discontinuously passive layer of $\mathrm{Fe}_{2} \mathrm{O}_{3}$, formed during the high-temperature manufacturing process [14]. Additionally, a mixture of nonstoichiometric iron oxide and oxyhydroxide species may form in storage

\footnotetext{
* Corresponding author. Tel.: +88622362 5373; fax: +886223928821.

E-mail address: d90541008@ntu.edu.tw (Y.H. Liou).
}

$[15,16]$. Prior to pretreatment, various valences of iron oxides predominantly controlled the reaction rate by restricting the diffusion of contaminants into the active sites on the iron surface. Thus, a pretreatment method is needed to remove the passive oxides layers to activate the iron surface.

The pretreatment methods, acid washing $[2,4,17]$, chloride ions treatment [18] and sonication [15], were proposed to remove the passive oxide layer prior to decontamination reaction, thereby increasing the available reactive sites and increasing the rate of the pollutant degradation at early time. At later time, the effect of both acid washing and chloride ions treatment provide little improvement. Evidences show that many fine iron particles were lost [16], and the oxidation rate of iron was highly accelerated due to increase concentrations of adsorbed $\mathrm{H}^{+}$and $\mathrm{Cl}^{-}$[4]. High energies inputs were employed for the pretreatment by sonication [15]. Thus, those 
pretreatment methods may not be effective and convenient techniques for improving the drawbacks of iron.

In this study, the surface of iron was heated using reducing gas $\left(20 \mathrm{vol} . \% \mathrm{H}_{2} / \mathrm{N}_{2}\right)$ at $400{ }^{\circ} \mathrm{C}$ for $3 \mathrm{~h}$ prior to the reduction of $40 \mathrm{mg} \mathrm{N} \mathrm{L}^{-1}$ nitrate. The objective of this research was to investigate the effect of pretreatment of commercial iron on the nitrate reduction rates over a range of $10-45^{\circ} \mathrm{C}$. Specially, the BET $\mathrm{N}_{2}$ adsorption analysis, scanning electron microscopy (SEM) and temperature programmed reduction (TPR) were used to compare the physical changes of the pretreated and nonpretreated iron surface.

\section{Experimental}

\subsection{Chemicals}

Potassium nitrate was purchased from Aldrich $(99+\%$, Milwaukee, WI). The chemicals used was $N$-[2-hydroxyethyl]piperazine- $N^{\prime}$-[2-ethanesulfonic acid] acid (HEPES, Sigma) for $\mathrm{pH}$ control. The zero valent iron used was iron powder (99.6\%, electrolytic and finer than 100 mesh) obtained from J.T. Baker. All aqueous solutions were made in water purified with a Milli- $\mathrm{Q}^{\mathrm{TM}}$ system $\left(18.2 \mathrm{M} \Omega \mathrm{cm}^{-1}\right)$. The desired concentrations of nitrate, $40 \mathrm{mg} \mathrm{N} \mathrm{L}^{-1}$, in Arpurged water were prepared by dilution of a $1000 \mathrm{mg} \mathrm{N} \mathrm{L}^{-1}$ stock solution. Adding the buffer, $40 \mathrm{mM}$ HEPES, to control the $\mathrm{pH}$ of the solution at the range 6.5-7.5.

\subsection{Surface treatment}

The iron was heated in a flow of $\mathrm{H}_{2} / \mathrm{N}_{2}$ (20 vol.\%, $50 \mathrm{~mL} \mathrm{~min}^{-1}$ ) from ambient to $400{ }^{\circ} \mathrm{C}$. Keeping at $400{ }^{\circ} \mathrm{C}$ for $3 \mathrm{~h}$ to completely reduce the aged oxide layer on the iron surface into zero valences. After cooling down to room temperature, the flow of $\mathrm{H}_{2} / \mathrm{N}_{2}$ was then replaced by Helium gas $\left(50 \mathrm{~mL} \mathrm{~min}^{-1}\right)$ to purge the reduced sample for $10 \mathrm{~min}$. The $\mathrm{H}_{2}$-reduced iron must be stored in a drying box. When a loss of reactivity of aged iron occurs due to a build up of iron oxide layers, the same process was used to recover its activity after drying iron particles.

\subsection{Characteristics of iron surface}

Surface areas were determined by BET $\mathrm{N}_{2}$ adsorption analysis on a Coulter SA3100 surface area analyzer (Coulter Co., Hialeach, FL). The morphology of the surface of the iron was viewed with scanning electron microscopy (SEM). Temperature programmed reduction (TPR) studies were performed to determine the quantity of iron oxide with the apparatus similar to that described previously [19]. In that, a flow of $\mathrm{H}_{2} / \mathrm{Ar}$ (20 vol.\%, $100 \mathrm{~mL} \mathrm{~min}^{-1}$ ) was used as reducing gas. The oven temperature was programmed from ambient to $450{ }^{\circ} \mathrm{C}$ at rate of $10^{\circ} \mathrm{C} \mathrm{min}^{-1}$ and keeping it at $450{ }^{\circ} \mathrm{C}$ for $1 \mathrm{~h}$. The peak of $\mathrm{H}_{2}$ consumption was assigned to $\mathrm{Fe}(\mathrm{III}) \rightarrow \mathrm{Fe}^{0}$, represented as Eq. (1).

$\mathrm{Fe}_{2} \mathrm{O}_{3}+3 \mathrm{H}_{2} \rightarrow 2 \mathrm{Fe}^{0}+3 \mathrm{H}_{2} \mathrm{O}$

The quantity of $\mathrm{H}_{2}$ consumption was obtained by comparing the area of this peak to that of $1 \mathrm{~mL} \mathrm{H}_{2}(40.9 \mu \mathrm{mol}$ at $1 \mathrm{~atm}, 25^{\circ} \mathrm{C}$ ) passing through the reactor of TPR. Simultaneously, the total number of $\mathrm{Fe}_{2} \mathrm{O}_{3}$ atoms was calculated by multiplying by a factor (1/2), consistent with the stoichiometry of Eq. (1).

\subsection{Reactor system}

All experiments as function of time were performed with $65 \mathrm{~mL}$ serum bottles. In each bottle, $0.5 \mathrm{~g}$ iron particles and $65 \mathrm{~mL}$ of Ar-purged buffered $40 \mathrm{mg} \mathrm{NL}^{-1}$ solution were added, leaving no headspace. Immediately, the vials were capped with Teflon silicone septa and aluminum seals, and then mixed at $200 \mathrm{rpm}$ using a reciprocal shaker water bath (Yihder, BT-350R) at 10, 25, 35 and $45^{\circ} \mathrm{C}$.

\subsection{Sample analysis}

One milliliter of aqueous solution was collected from the serum bottle by a syringe through the septa, and simultaneously another needle was used to inject argon gas to replace the liquid removal. Nitrate was measured using an ion chromatograph (Dionex DX-100 ${ }^{\mathrm{TM}}$ ).

\section{Results and discussion}

\subsection{Effect of surface pretreatment}

The reaction rate was evaluated with nitrate solution ( $40 \mathrm{mg} \mathrm{N} \mathrm{L}^{-1}$ ) containing $0.5 \mathrm{~g}$ of pretreated iron, and as comparison with nonpretreated iron (Fig. 1). The reduction of nitrate followed pseudo-first-order kinetics with respect to

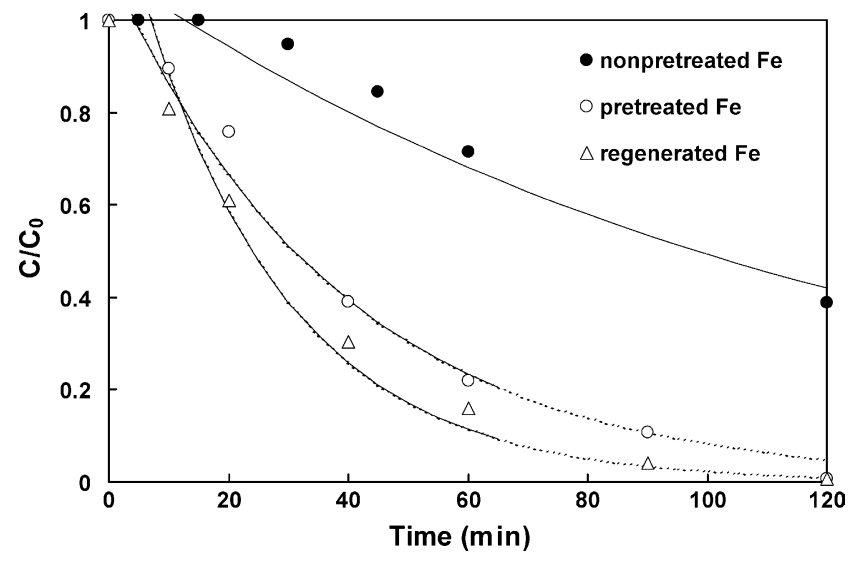

Fig. 1. Kinetics of nitrate removal as function of reaction time in the presence of nonpretreated iron, pretreated iron and regenerated iron at $25^{\circ} \mathrm{C}$. 
the concentration of nitrate:

$r=\frac{-\mathrm{d}\left[\mathrm{NO}_{3}{ }^{-}\right]}{\mathrm{d} t}=k_{\mathrm{obs}}\left[\mathrm{NO}_{3}{ }^{-}\right]$

where $k_{\text {obs }}$ is the observed pseudo-first-order reaction rate constant $\left(\mathrm{min}^{-1}\right)$. The reduction of nitrate using the nonpretreated iron exhibited a stagnation phenomenon at the first $20 \mathrm{~min}$ of the reaction, and then attenuated at rate of $0.0081 \mathrm{~min}^{-1}$. A build up of iron oxide layer, resulting from contacting with the ambient oxygen during manufacturing and transportation process, exhibited a stagnation phenomenon during the reduction of nitrate. The iron was heated in a flow of $\mathrm{H}_{2} / \mathrm{N}_{2}$ gas at $400{ }^{\circ} \mathrm{C}$ to reduce the passive iron oxides into zero valence and then added into $65 \mathrm{~mL}$ of Arpurged buffered $40 \mathrm{mg} \mathrm{N} \mathrm{L}^{-1}$ solution. The results indicated that not only the $k_{\mathrm{obs}}$ was promoted by a factor of about 4.7-0.0384 $\mathrm{min}^{-1}$ but also the lag of the early period disappeared. Generally, the nitrate reduction rate is proportional to the amounts of exposed iron surface. Therefore, regarding to the iron activity per unit surface area, the $k_{\mathrm{obs}}$ is necessarily to normalize according to the surface area and the mass concentration of iron particles. The surface area normalized rate constant $\left(k_{\mathrm{SA}}\right)$ can be calculated by Eq. (3).

$k_{\mathrm{SA}}=\frac{k_{\mathrm{obs}}}{\rho_{\mathrm{a}}}$

$\rho_{\mathrm{a}}$ is the surface area concentration of iron in $\mathrm{m}^{2} \mathrm{~L}^{-1}$, and here, the $k_{\mathrm{SA}}$ is a parameter of assessment of the overall surface reactivity. The BET surface areas are $0.516 \mathrm{~m}^{2} \mathrm{~g}^{-1}$ for nonpretreated iron and $0.391 \mathrm{~m}^{2} \mathrm{~g}^{-1}$ for pretreated iron (Table 1). The value of $\rho_{\mathrm{a}}$ was $3.97 \mathrm{~m}^{2} \mathrm{~L}^{-1}$ for nonpretreated iron and $3.01 \mathrm{~m}^{2} \mathrm{~L}^{-1}$ for pretreated iron in the batch experiments. Thus the $k_{\mathrm{SA}}$ for nonpretreated and pretreated iron were 0.0020 and $0.0128 \mathrm{~min}^{-1} \mathrm{~m}^{-2} \mathrm{~L}$ as shown in Table 1 . The reactivity of pretreated iron was higher relative to nonpretreated iron as indicated by a larger $k_{\mathrm{SA}}$ for pretreated iron. Hence the active site concentration on pretreated iron was increased due to the transformation of iron oxides into zero valences by $\mathrm{H}_{2}$ reduction.

\subsection{Characteristics of iron surface}

The characteristics of exposed iron surfaces, nonpretreated and reduced by $\mathrm{H}_{2}$, were compared. Clearly, using the $\mathrm{H}_{2}$-reducing pretreatment method, the specific surface area of pretreated iron decreased as compared with nonpretreated iron (Table 1). The morphology of these two iron surfaces were analyzed using SEM. The pretreated iron in Fig. 2(a)
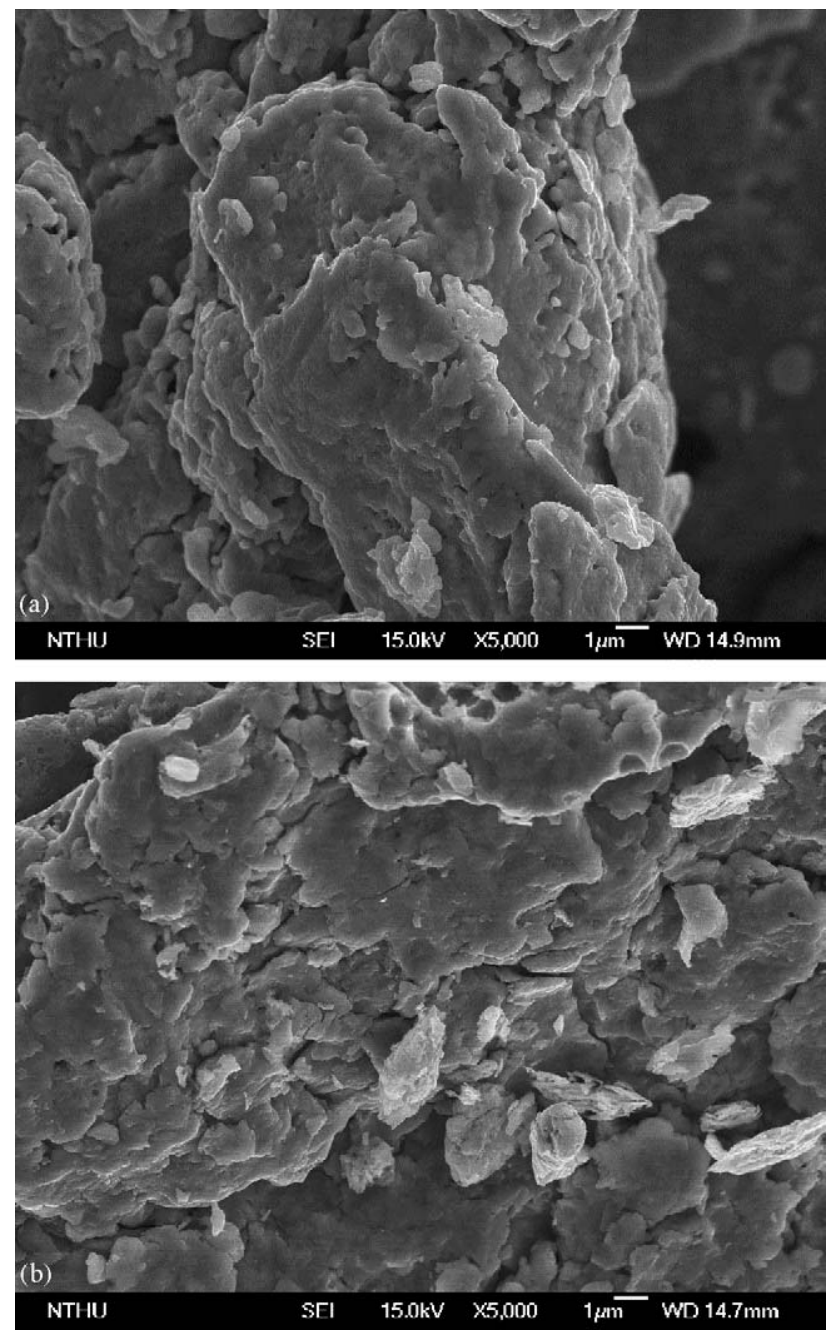

Fig. 2. SEM images of (a) pretreated iron surface and (b) nonpretreated iron surface with a magnification of $5000 \times$.

exhibited visibly cleaner without pitting and cracking relative to the nonpretreated iron in Fig. 2(b). This change was due to the reduction of fluffy iron oxides on iron surface into solid zero-valence and therefore the specific surface area of pretreated iron was decreased.

The amount of $\mathrm{H}_{2}$ consumed by the samples of iron (nonpretreated and pretreated iron) was obtained by TPR (Fig. 3); the total number of $\mathrm{Fe}_{2} \mathrm{O}_{3}$ atoms was calculated by multiplying by a factor consistent with the stoichiometry of Eq. (1). Then, the total mass of $\mathrm{Fe}_{2} \mathrm{O}_{3}$ on the surface of the iron was normalized to the specific surface area in the units of $\mathrm{mg} \mathrm{m}^{-2}$. Table 2 shows the relevant values. The $\mathrm{Fe}_{2} \mathrm{O}_{3}$

Table 1

The values of pseudo-first-order rate constants $\left(k_{\mathrm{obs}}\right)$ and surface area normalized rate constant $\left(k_{\mathrm{SA}}\right)$ of nitrate reduction under each reductant

\begin{tabular}{lllll}
\hline Reductants & BET specific surface area $\left(\mathrm{m}^{2} \mathrm{~g}^{-1}\right)$ & $k_{\mathrm{obs}}\left(\mathrm{min}^{-1}\right)$ & $k_{\mathrm{SA}}\left(\mathrm{min}^{-1} \mathrm{~m}^{-2} \mathrm{~L}\right)$ & $\begin{array}{l}\text { Observed first-order rate constant of each } \\
\text { reductants with coefficient of determination }\left(r^{2}\right)\end{array}$ \\
\hline Nonpretreated iron & 0.516 & 0.0081 & 0.0020 & 0.95 \\
Pretreated iron & 0.391 & 0.0384 & 0.0128 & 0.99 \\
Regenerated iron & 0.442 & 0.0410 & 0.0121 & 0.98 \\
\hline
\end{tabular}


Table 2

$\mathrm{Fe}_{2} \mathrm{O}_{3}$ mass per unit exposed iron surface area for nonpretreated, pretreated and regenerated iron

\begin{tabular}{llll}
\hline & $\begin{array}{l}\mathrm{H}_{2} \text { consumption of } 1 \mathrm{~g} \text { iron } \\
\text { sample }(\mu \mathrm{mol})(1)\end{array}$ & $\begin{array}{l}\mathrm{H}_{2} \text { consumption per unit exposed iron surface } \\
\operatorname{area}\left(\mu \mathrm{mol} \mathrm{m}^{-2}\right)(2)=\frac{(1)}{(\mathrm{BET} \text { surface area }) \times 1 \mathrm{~g}}\end{array}$ & $\begin{array}{l}\mathrm{Fe}_{2} \mathrm{O}_{3} \text { mass per unit exposed iron surface area } \\
\left(\mathrm{mg} \mathrm{m}^{-2}\right)(3)=\frac{(2) \times 10^{-6} \times 55.8 \times 10^{3}}{3}\end{array}$ \\
\hline Nonpretreated iron & 117.4 & 227.5 & 8.46 \\
Pretreated iron & 15.6 & 39.9 & 1.48 \\
Regenerated iron & 18.9 & 42.8 & 1.59 \\
\hline
\end{tabular}

mass per unit exposed iron surface area of nonpretreated iron reached $8.46 \mathrm{mg} \mathrm{m}^{-2}$. This sample had been unsealed for 9 months and then stored in a drying box. After pretreatment by reducing with $\mathrm{H}_{2}$, the iron oxides quickly converted into zero-valent iron, and only few $\mathrm{O}$ atoms remained on the $\mathrm{H}_{2}$ reduced iron surface.

\subsection{Temperature effect}

Temperature is an important factor in control the reaction rate of chemical or physical processes. Su and Puls [17] demonstrated that the calculated activated energy $\left(E_{\mathrm{a}}\right)$ by evaluating the rate constants over a temperature range can be viewed as the quality of energy of the slowest reaction step. Thus, the rate-limiting step in the reaction of a metallic iron-nitrate-water system must be either a chemical reaction or a diffusion process, as determined by $E_{\mathrm{a}}$ value. Generally, a physical process, diffusion, requires less energy than a chemical process, such as reduction. Su and Puls [17] stated that an $E_{\mathrm{a}}$ value of around $15 \mathrm{~kJ} \mathrm{~mol}^{-1}$ was the most often cited value for diffusion-controlled processes. Firstly, the reduction rate constants $\left(k_{\text {obs }}\right)$ in Eq. (2) were evaluated in a batch system at $10,25,35$, and $45^{\circ} \mathrm{C}$ individually in contact with nonpretreated and pretreated iron, respectively (Fig. 4). The $k_{\text {obs }}$ measured in batch experiments exhibited a temperature dependency consistent with the Arrhenius equation:

$k_{\mathrm{obs}}=A \exp \frac{-E_{\mathrm{a}}}{R T}$

where $E_{\mathrm{a}}$ is the activation energy $\left(\mathrm{kJ} \mathrm{mol}^{-1}\right), A$ the preexponential factor $\left(\mathrm{min}^{-1} \mathrm{~m}^{-2} \mathrm{~L}\right), R$ the molar gas constant

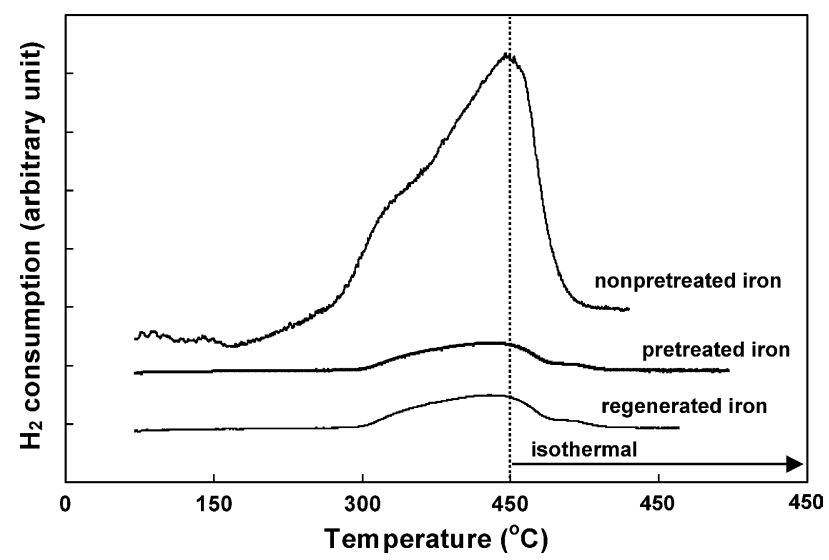

Fig. 3. Consumption of $\mathrm{H}_{2}$ during temperature programmed reduction of nonpretreated, pretreated and regenerated iron.
(0.008314 $\left.\mathrm{kJ} \mathrm{mol}^{-1} \mathrm{~K}^{-1}\right)$, and $T$ is the absolute temperature $(\mathrm{K})$. The activation energy for the reaction was obtained from the slope of a plot of $\ln \left(k_{\mathrm{obs}}\right)$ versus $1 / T$ using linear least-square analysis. Table 3 presents the relevant values. The $E_{\mathrm{a}}$ calculated using Arrhenius law were 46.0 and $32.0 \mathrm{~kJ} \mathrm{~mol}^{-1}$ for nonpretreated and pretreated iron, respectively. This result indicates temperature effect was more significant for nonpretreated iron relative to pretreated iron. These data are large enough to indicate that the chemical reactions, rather than diffusion, dominate the rate of nitrate loss in the iron-water systems. The difference of $E_{\mathrm{a}}$ between nonpretreated and pretreated iron could be a result of different active sites on iron surface controlling the nitrate reduction.
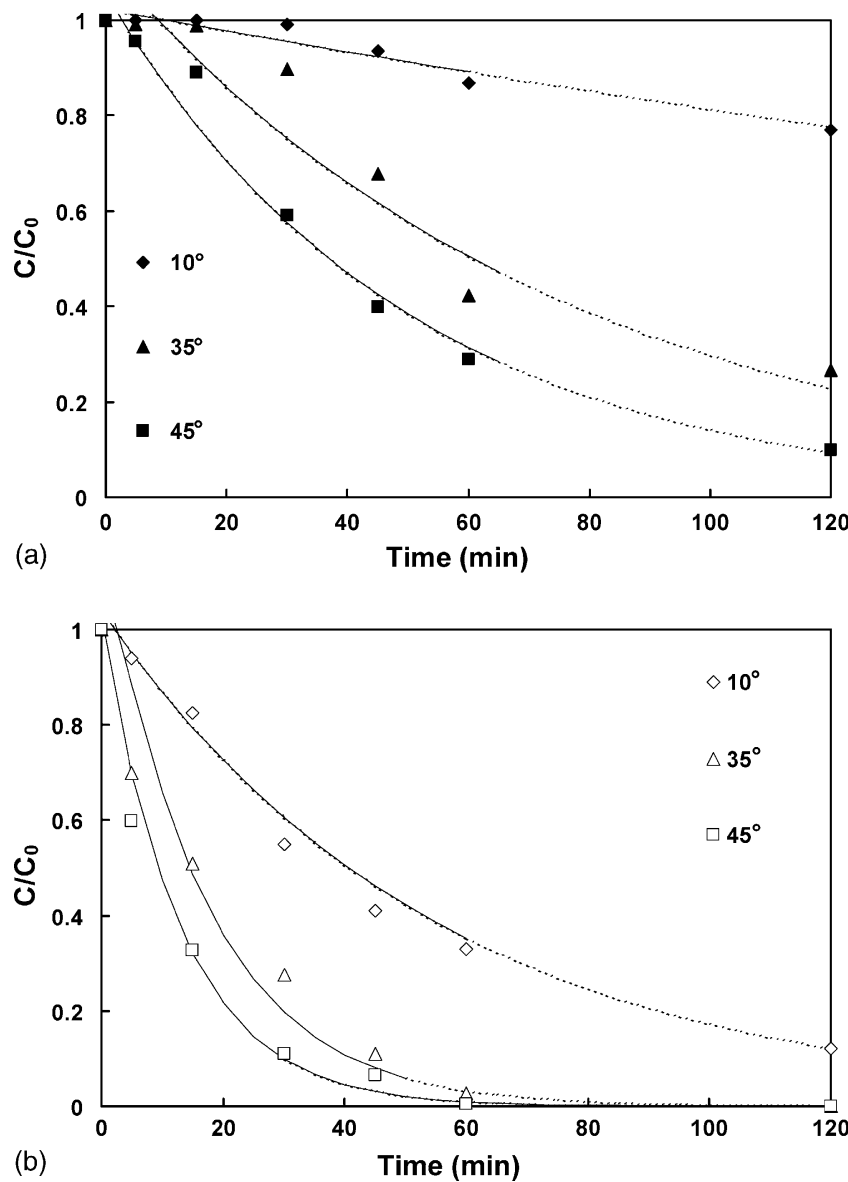

Fig. 4. Kinetics of nitrate removal as function of reaction time in the presence of (a) nonpretreated iron and (b) pretreated iron over the temperature range of $10-45^{\circ} \mathrm{C}$. 
Table 3

Observed first-order rate constants at $10,25,35$ and $45^{\circ} \mathrm{C}$ and activation energies for nonpretreated and pretreated iron

\begin{tabular}{lllll}
\hline Reductant & \multicolumn{2}{l}{ Observed first-order rate constant $\left(k_{\mathrm{obs}}, \mathrm{min}^{-1}\right)$} & \multicolumn{2}{c}{ Activation energy $\left(\mathrm{kJ}\right.$ mol $\left.{ }^{-1}\right)$} \\
\cline { 2 - 4 } & $T=10^{\circ} \mathrm{C}$ & $T=25^{\circ} \mathrm{C}$ & $T=35^{\circ} \mathrm{C}$ & 0.0202 \\
\hline Nonpretreated iron & 0.0023 & 0.0081 & 0.0121 & 0.0779 \\
Pretreated iron & 0.018 & 0.0384 & 0.0602 & 36.0 \\
\hline
\end{tabular}

\subsection{Regeneration}

The removal of passive oxide layer using acid washing and sonication to restore the reactivity of metallic iron has been reported. Gui et al. [20] pointed out that the acid solution $\left(\mathrm{H}_{2} \mathrm{SO}_{4}\right)$ for $\mathrm{Ni} / \mathrm{Fe}$ regeneration removed some of the covered corrosion products, thereby making iron and nickel more accessible to the NDMA molecules in the solution. However, a loss for recoverable active sites on $\mathrm{Ni}$ was caused through the regeneration process with acid solution. The use of sonication to regenerate the surface reactivity removing superficial deposits did not successfully remove oxide layers and thereby was no different in reaction rate from the nonsonicated samples [21]. This study used a flow of $\mathrm{H}_{2} / \mathrm{N}_{2}\left(20 \mathrm{vol} . \%, 50 \mathrm{~mL} \mathrm{~min}^{-1}\right)$ to flush the aged iron surface at $400{ }^{\circ} \mathrm{C}$ in a closed oven, similar to the pretreatment method described above. The regeneration experiment was performed to aged iron with continual soaking in nitrate solution for 60 days. Before regenerating, the reactivity of these aged iron decreased $50-60 \%$ (about $0.0217 \mathrm{~min}^{-1}$ ) as compared to the fresh pretreated iron. As shown in Table 1, the $k_{\mathrm{obs}}$ was $0.0410 \mathrm{~min}^{-1}$ and the $k_{\mathrm{SA}}$ was $0.0121 \mathrm{~min}^{-1} \mathrm{~m}^{-2} \mathrm{~L}$. The value of $k_{\mathrm{SA}}$ for regenerated iron was similar to that for fresh pretreated iron whereas the value of $k_{\mathrm{obs}}$ was rose by a factor of about 1.1 due to the increase in the BET specific surface area. The reactivity of the aged iron was completely restored. Unlike acid washing process, no acid wastewater and sludge were produced using $\mathrm{H}_{2}$ reduction process. Hence $\mathrm{H}_{2}$ reduction process is an effective and promising method to activate iron surface.

\section{Conclusions}

Iron surface was activated using hydrogen gas at $400^{\circ} \mathrm{C}$ to degrade nitrate $\left(40 \mathrm{mg} \mathrm{N} \mathrm{L}^{-1}\right)$ in a HEPES buffer solution at $\mathrm{pH}$ value between 6.5 and 7.5. The results obtained in this study have demonstrated the following:

(1) Compared with the nonpretreated iron, the both values of $k_{\mathrm{obs}}$ and $k_{\mathrm{SA}}$ were increased 4.7 and 6 times by pretreated iron, and the lag of the early period disappeared.

(2) The physical changes on iron surfaces were investigated by BET analysis, SEM and TPR. The results indicated the increase in active site concentration on the pretreated iron resulted from the transformation of iron oxides into zero valence.
(3) The values of $E_{\mathrm{a}}$ of nitrate reduction over the temperature range of $10-45^{\circ} \mathrm{C}$ were $46.0 \mathrm{~kJ} \mathrm{~mol}^{-1}$ for nonpretreated iron, and $32.0 \mathrm{~kJ} \mathrm{~mol}^{-1}$ for pretreated iron, indicating chemical reaction control, rather than diffusion.

(4) The reactivity of aged iron with continual soaking in nitrate solution for 60 days was completely restored by hydrogen gas at $400^{\circ} \mathrm{C}$.

\section{Acknowledgement}

The authors would like to thank the National Science Council of the Republic of China for financially supporting this research under contract no. NSC 93-2211-E-002-035.

\section{References}

[1] R.W. Gillham, S.F. O'Hannesin, Enhanced degradation of halogenated aliphatics by zero-valent iron, Ground Water 32 (1994) 958-967.

[2] L.J. Matheson, P.G. Tratnydk, Reductive dehalogenation of chlorinated methanes by iron metal, Environ. Sci. Technol. 28 (1994) 2045-2053.

[3] W.S. Orth, R.W. Gillham, Dechlorination of trichloroethene in aqueous solution using $\mathrm{Fe}^{0}$, Environ. Sci. Technol. 30 (1996) 66-71.

[4] A. Agrawal, P.G. Tratnyek, Reduction of nitro aromatic compounds by zero-valent iron metal, Environ. Sci. Technol. 30 (1996) 153-160.

[5] G.D. Sayles, G. You, M. Wang, M.J. Kupferle, DDT, DDD, and DDE dechlorination by zero-valent iron, Environ. Sci. Technol. 31 (1997) 3448-3454.

[6] C.P. Huang, H.W. Wang, P.C. Chiu, Nitrate reduction by metallic iron, Water Res. 32 (1998) 2257-2264.

[7] I.F. Cheng, R. Muftikian, Q. Fernando, N. Korte, Reduction of nitrate to ammonia by zero-valent iron, Chemosphere 35 (1997) 2689-2695.

[8] J. Kielemoes, P.D. Boever, W. Verstraete, Influence of denitrification on the corrosion of iron and stainless steel powder, Environ. Sci. Technol. 34 (2000) 663-671.

[9] M.J. Alowitz, M.M. Scherer, Kinetic of nitrate, nitrite and $\mathrm{Cr}(\mathrm{VI})$ reduction by iron metal, Environ. Sci. Technol. 36 (2001) 299-306.

[10] P. Westerhoff, Reduction of nitrate, bromate, and chlorate by zero valent iron $\left(\mathrm{Fe}^{0}\right)$, J. Environ. Eng. 129 (2003) 10-16.

[11] A.R. Pratt, D.W. Blowes, C.J. Ptacek, Products of chromate reduction on proposed subsurface remediation material, Environ. Sci. Technol. 31 (1997) 2492-2498.

[12] S.M. Ponder, J.G. Darab, T.E. Malloiuk, Remediation of $\mathrm{Cr}(\mathrm{VI})$ and $\mathrm{Pb}(\mathrm{II})$ aqueous solutions using supported, nanoscale zero-valent iron, Environ. Sci. Technol. 34 (2000) 2564-2569.

[13] S. Franz-George, C. Segebade, M. Hedrich, Behaviour of uranium in iron-bearing permeable reactive barriers: investigation with $237 \mathrm{U}$ as a radioindicator, Sci. Total Environ. 307 (2003) 231-243.

[14] K. Ritter, M.S. Odziemkowski, R.W. Gillham, An in situ study of the role of surface films on granular iron in the permeable iron wall technology, J. Contamin. Hydrol. 55 (2002) 87-111. 
[15] N. Ruiz, S. Seal, D. Reinhart, Surface chemical reactivity in selected zero-valent iron samples used in groundwater remediation, J. Hazard. Mater. B 80 (2000) 107-117.

[16] S.F. Cheng, S.C. Wu, The enhancement methods for the degradation of TCE by zero-valent metals, Chemosphere 41 (2000) 1263-1270.

[17] C. Su, R.W. Puls, Kinetics of trichloroethene reduction by zerovalent iron and tin: pretreatment effect, apparent activation energy, and intermediate products, Environ. Sci. Technol. 33 (1999) $163-168$.

[18] J. Gotpagar, S. Lyuksyutov, E. Cohn, D. Bhattacharyya, Reductive dechlorination of trichloroethylene with zero-valent iron: surface pro- filing microscopy and rate enhancement studies, Langmuir 15 (1999) $8412-8420$.

[19] G.C. Bond, S.N. Namijo, An improved procedure for estimation the metal surface area of supported copper catalysts, J. Catal. 118 (1989) $511-512$.

[20] L. Gui, R.W. Gillham, M.S. Odziemkowski, Reduction of $n$ nitrosodimethylamine with granular iron and nickel-enhanced iron. 1. Pathway and kinetics, Environ. Sci. Technol. 34 (2000) 3489-3494.

[21] A.M. Moore, C.H. De Leon, T.M. Young, Rate and extent of aqueous perchlorate removal by iron surfaces, Environ. Sci. Technol. 37 (2003) 3189-3198. 